\title{
Research on Legal Regulation of the UNSC's Addressing the Issue of Climate Refugees
}

\author{
Bingyuuan Huang ${ }^{1, \uparrow, *}$ Yifei Ma ${ }^{2, \dagger}$, Jiaxuan Ruan ${ }^{3, \dagger}$, Jianyue Tang ${ }^{4, \dagger}$
}

\author{
${ }^{1}$ Hunan Police Academyg, Changsha, Hunan, China \\ ${ }^{2}$ Law school, Ocean University of China, Qingdao, Shandong, China \\ ${ }^{3}$ Law school, University of Science and Technology Beijing, Beijing, Beijing, China \\ ${ }^{4}$ Law school, South-Central Minzu University, Wuhan, Hubei, China \\ *Jiaxuan Ruan.Email: ${ }^{141808099 @ x s . u s t b . e d u . c n}$ \\ ${ }^{+}$These authors contributed equally.
}

\begin{abstract}
Climate change has caused a large number of issues related to climate refugee, which have threatened international peace and security. So this requires action by the UN Security Council. Firstly, the current situation of climate refugees and three reasons for the difficulties of climate refugees' rights relief includes the unclear definition of climate refugees in international refugee law, the institutional limitations of international human rights law and climate law, and a lack of the UNSC' s call and responsibility allocation to all countries. Secondly, there exists exertion and deficiency of statutory authority, and the exertion of policy making power, temporary disposal power and call on the state power are insufficient. Finally, the right relief measures of climate refugees includes redefining the related concepts of climate refugees, constructing international agreements between countries, and using international customary law to achieve relief.
\end{abstract}

Keywords: Climate refugees, the UN Security Council, climate refugee's right of migration, rights relief.

\section{THE STATUS QUO AND CAUSES OF CLIMATE REFUGEES}

\subsection{Current Status Of Climate Change And Climate Refugees}

Nowadays, due to the climate change, the rights of climate refugees are threatened, and they also have an adverse impact on international peace and security. With global warming and other climate changes, extreme weather and rising sea levels had made the phenomenon of climate refugees more and more common, and the rights of climate refugees have been seriously threatened. When migrating from one country to another, climate refugees are faced with xenophobia and hostility, arbitrary personal restrictions, human trafficking, rape, and violence. At the same time, the migration of climate refugees will also lead to the spread of diseases. Climate change has led to malaria and malnutrition worldwide, and the migration of climate refugees will cause the widespread spread of this disease [1]. In addition, climate migration will disrupt the stable resource allocation mechanism of the host country, causing local conflicts for resource. For example, in Darfur, the Central African Republic, northern Kenya and Chad, competition for water, land and other essential resources for survival caused serious occasional regional armed conflicts, posing a huge threat to local peace and stability [2]. Obviously, this situation urgently requires the UN Security Council to take relevant actions to protect the rights of climate refugees.

\subsection{Difficulties In Climate Refugee Rights Protection}

The Guiding Principles on Internal Displacement drafted by the United Nations in 1998 provides internal displacement with protection, but current international laws only provide very limited protection for climate refugees [3]. The international refugee law cannot be applied to the issue of climate refugees, the definition and status of climate refugees are still unclear in the international community. At the same time, international human rights law and international climate law have institutional limitations in dealing with climate refugee 
issues. Besides, the responsibilities of countries for climate refugees cannot be clarified through multilateral agreements.

\subsubsection{The Definition Of Climate Refugee In International Refugee Law Is Unclear}

The definition of climate refugee in international refugee law is unclear, and the range of refugee is too small. 1A(2) of The United Nations Refugee Convention define refugees, and The Protocol relating to the Status of Refugees also interprets the definition of refugees. That is, "refugee" refers to "As a result of events occurring before 1 January 1951 and owing to wellfounded fear of persecution for reasons of race, religion, nationality, membership of a particular social group or political opinion, is outside the country of his nationality and is unable or, owing to such fear, is unwilling to avail himself of the protection of that country; or who, not having a nationality and being outside the country of his former habitual residence as a result of such events, is unable or, owing to such fear, is unwilling to return to it. "It can be seen from this that "refugees" must contain three elements: being outside the country of his nationality; the persecution must be based on a limited number of reasons; and they cannot or are unwilling to take advantage of the protection of their home country [4]. This definition makes it difficult for people displaced by climate change to be protected. First, only people who cross the border of a country can be refugees. But in fact, some of climate refugees does not cross the border, and they just seeks remedy for rights within a country. Unless there are other reasons to prove the existence of "persecution", these people cannot be protected. Second, "climate change" can hardly be characterized as "persecution". "Persecution" means an act that has a particularly bad influence and violates human rights due to its inherent nature or cumulative influence. Although the negative effects of climate change are harmful, they can not be defined as "persecution" according to the current international and domestic laws. Finally, the persecution of refugees must be based on five limited reasons: race, religion, nationality, members of special social groups or political opinions, and climate change is not included. In most cases, people displaced by climate change cannot be recognized as refugees. However, there are still some exceptions. People who intend to move to other countries can regard certain actions of the government as "persecution", and according to The United Nations Refugee Convention they can get some protection [5].

\subsubsection{Institutional Limitations In International Human Rights Law And Climate Law}

In most cases, if climate refugees' rights are threatened, they can't seek help from the international human rights law because of limitations inside the law.
The application of international human rights law presupposes that human rights are directly violated, but the impact of climate change is indirect, rather than direct and sudden. For example, greenhouse gas emissions must be accumulated to a certain level to affect basic human health. In fact, although the loss caused by climate change is indirect, once it causes an impact, it will be global and irreparable. It is also difficult to prove at the legal level that a country's greenhouse gas emissions directly violate the specific human rights of specific groups of people [6]. And it cannot be considered that the country's inaction has caused the violation of the human rights because most countries have adopted the positive attitude towards climate change. Therefore, the rights of climate refugees are hardly protected by international human rights law.

International climate laws do not provide specific protection for climate refugees. At present, international climate law mainly includes the United Nations Framework Convention on Climate Change, the Kyoto Protocol and the Paris Agreement, but none of them regulates the issue of climate refugees. The United Nations Framework Convention on Climate Change and the Kyoto Protocol do not define climate refugees, while the Paris Agreement elaborates on population migration and displacement caused by climate change. But there are still many shortcomings in these documents: Firstly, the Climate Displacement Task Force (TFD) established by the agreement is only responsible for research and technical support, and cannot formulate legal regulations, so it is difficult to provide corresponding protection for climate refugees. Secondly, the provisions are noncompulsory and there are only principle-based rules, which cannot provide real protection for refugee in practice.

\subsubsection{Lack Of The UNSC Call And Responsibility Allocation To All Countries}

The UNSC does not call on countries to protect rights of refugees and there is no international agreement for responsibility allocation to all countries. The issue of climate change involves various economic fields such as industry and agriculture. Therefore, many countries take their own national interests as a priority, and then consider the cost of solving environmental problems. Besides, their attitudes towards solving the climate change are ambiguous. The environmental agreements also do not have obvious coercive force: the provisions on the obligations of countries to protect the environment and the responsibilities of "climate refugees" only require the parties to respect, promote and give consideration to the issue of climate refugees, that is, the country of origin rather than the international society bears the primary responsibility for climate-displaced persons. There are also many loopholes in the application of the "polluter pays" principle. For example, is it reasonable to make 
those developing countries or victims of climate change responsible for climate issues? This is an unresolved problem. When climate refugees issue related to transnational migration, the international distribution of responsibilities between the home country and the immigration country is not clear. In recent years, there are some rules of international law mentioning the human rights protection obligations of one country to the nationals of another country, but the golden rule of "effective control" are always popular. And the golden rule of "effective control" means that a country only has the obligation to protect the its citizens that it can effectively control. It made country generally does not have the obligation to protect the human rights of people outside its territory or jurisdiction.

\section{THE EXERTION AND DEFICIENCY OF STATUTORY AUTHORITY}

\subsection{Statutory Authority}

According to the UN Charter, the UN Security

Council has the following statutory authorities.

Table 1 Statutory authorities of the UN Security Council

\begin{tabular}{|c|c|c|}
\hline Nane & Content & Authority \\
\hline Article 1 & $\begin{array}{l}\text { 1. To achieve international co-operations in solving international problems of an economic, social, } \\
\text { cultural, or humanitarian character, and in promoting and encouraging respect for human rights and for } \\
\text { fundamental freedoms for all without distinction as to race, sex, language, or religion; }\end{array}$ & $\begin{array}{l}\text { To provide humanitarian } \\
\text { assistance to refugees and help } \\
\text { them tide over difficulties. }\end{array}$ \\
\hline Article 25 & $\begin{array}{l}\text { The Member's of the United Nations agree to accept and carry out the decisions of the Security Council } \\
\text { in accordance with the present Charter. }\end{array}$ & 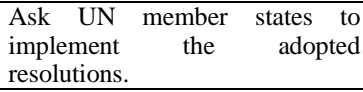 \\
\hline Article 27 & $\begin{array}{l}\text { 1. Each member of the Security Council shall have one vote. } \\
\text { 2. Decisions of the Security Council on procedural matters shall be made by an affirmative vote of nine } \\
\text { members. } \\
\text { 3. Decisions of the Security Council on all other matters shall be made by an affirmative vote of nine } \\
\text { members including the concurring votes of the permanent members; provided that, in decisions under } \\
\text { Chapter VI, and under paragraph } 3 \text { of Article } 52 \text {, a party to a dispute shall abstain from voting. }\end{array}$ & $\begin{array}{l}\text { Policies can be made by the vote } \\
\text { of the members of the Security } \\
\text { Council. }\end{array}$ \\
\hline Article 29 & The Security Council may establish such subsidiary organs. & $\begin{array}{l}\text { The establishment of the refugee } \\
\text { office and other relevant auxiliary } \\
\text { organs. }\end{array}$ \\
\hline Article 41 & $\begin{array}{l}\text { The Security Council may decide what measures not involving the use of armed force are to be employed } \\
\text { to give effect to its decisions, and it may call upon the Members of the United Nations to apply such } \\
\text { measures. These may include complete or partial interruption of economic relations and of rail, sea, air, } \\
\text { postal, telegraphic, radio, and other means of communication, and the severance of diplomatic relations. }\end{array}$ & $\begin{array}{l}\text { To provide economic, } \\
\text { transportation and other non } \\
\text { military aid methods to solve the } \\
\text { refugee problem. }\end{array}$ \\
\hline Article 55 & $\begin{array}{l}\text { With a view to the creation of conditions of stability and well-being which are necessary for peaceful } \\
\text { and friendly relations among nations based on respect for the principle of equal rights and self- } \\
\text { determination of peoples, the United Nations shall promote: } \\
\text { a. higher standards of living, full employment, and conditions of economic and social progress and } \\
\text { development; } \\
\text { b. solutions of international economic, social, health, and related problems; and international cultural } \\
\text { and educational cooperation; and } \\
\text { c. universal respect for, and observance of, human rights and fundamental freedoms for all without } \\
\text { distinction as to race, sex, language, or religion. }\end{array}$ & $\begin{array}{l}\text { Obligation to help refugees in } \\
\text { general. }\end{array}$ \\
\hline
\end{tabular}

According to the purpose of Article 1 of the UN Charter, the UN Security Council has the authority to provide humanitarian assistance and help refugees. In solving the problem of climate refugees, the UN Security Council has the power to help them solve the problem, and solving the problem of climate refugees is the responsibility of the UN Security Council. According to articles 25 and 27, the UN Security Council has the right to make and implement decisions. In solving the problem of climate refugees, the UN Security Council can formulate appropriate policies according to the current specific situation, and guide member states to implement relief measures for climate refugees. According to Article 29, the UN Security Council has the right to set up the relevant auxiliary organs such as the refugee office to set up special agencies to solve the climate refugee problem for overall planning. According to Article 41, the UN Security Council has the right to provide economic, transportation and other non military assistance to solve the climate refugee problem. According to Article 55, the UN Security Council has and needs to fulfill its obligation to help climate refugees. The Security Council should call on Member States to jointly solve the problem of climate refugees.

\subsection{Insufficient Exertion Of Legal Power}

\subsubsection{Insufficient Exertion Of Policy Making Power}

According to the above table, the Charter of the United Nations stipulates that the Security Council of the United Nations can make policies through voting resolutions, and the member states of the United Nations also have the obligation to accept and implement the resolutions of the Security Council. However, Climate change is not included in the definition elements of refugee stipulated in the "Refugee Convention" and the "Convention on the Statues of refugees" . Nowadays, the climate refugee problem is becoming more and more serious. Due to the serious inadequacy of 
the coverage of existing international agreements, it is difficult for a large number of climate refugees to be included in the refugee scope, resulting in a large number of climate refugees unable to obtain timely international assistance. Faced with such a situation, the United Nations and the Security Council have not put forward a new bill to require a more comprehensive and precise definition of a refugee, which reflects the lack of its policy-making power.

\subsubsection{Insufficient Exertion Of Temporary Disposal Power}

Temporary disposal power, used here to indicate the United Nations authority to dispose of refugees on a temporary basis. For the treatment of refugees, UNHCR mainly adopts three methods: voluntary return to home, local integration and resettlement. For the first option, which is voluntary return to their hometown, most climate refugees cannot return to their hometown because of practical factors. For the second and third disposal methods, namely, local integration and resettlement, refugees mainly reside permanently in countries other than those of origin. But some climate refugees do not cross borders and are threatened only within their own countries of origin. At the same time, resettlement methods require refugees to meet UNHCR criteria, which is nothing more than difficult for climate refugees who are difficult to define as refugees. Therefore, the second and third methods of refugee treatment are also difficult to apply to climate refugees. And the large number of displaced climate refugees should not be left untreated by the UN and treated harshly by an imperfect definition of refugee. Pending a better refugee policy, the United Nations should actively apply the authority to deal with refugees on a temporary basis and provide humanitarian assistance to those climate refugees who cannot be defined as refugees.

\subsubsection{Insufficient Exertion Of Call On The State Power}

Call on the state power, used here to express the power of the United Nations to call on member states to fulfill their obligations under the Charter of the United Nations and to fulfill the requirements of the resolutions made. At present, the Security Council is only a conscious “political” actor, not a "legal” one. Therefore, the Council has no legal authority to impose sanctions on States that do not comply with their obligations under humanitarian law, human rights and refugee law [7] At the same time, the Global Refugee Compact, an international compact related to humanitarian assistance to refugees, is an international initiative and does not have mandatory legal force. Therefore, the United Nations has a large mandatory loophole in calling on countries to participate in the assistance of climate refugees.

\section{REDEFINING THE LEGAL RULES OF CLIMATE REFUGEES}

\subsection{A Redefinition Of The Legal Designation Of Climate Refugees}

According to existing international legal documents, UNHCR protects those who fear persecution because of their race, religion, nationality, political opinion or belonging to a particular social group, namely political refugees. It does not include forced migration due to environmental problems. Climate change cannot be included in the constitutive requirements of "refugee", so it cannot obtain legal refugee status in traditional international statutory law.

Climate refugees are a new problem that the international community has to face. Both the problem itself and the scale of their numbers justify and justify the establishment of a new convention. It is clear that the number of climate refugees is likely to be larger than the number of traditional refugees covered by the refugee convention. If environmental damage caused by climate change will cause the country finally disappear, coastal areas submerged, millions and millions of people are forced to migrate across national boundaries, then you should set up a dedicated to deal with these effects of legal protection mechanism, in the same way, the birth and development of a new problem, also asked to develop a new treaty accordingly in order to deal with the problem in law.

As the prefix of the word "refugees", climate can better clarify the specific reasons for the emergence of refugees. From the islands such as Tuvalu countries example can be concluded that the global warming as the main characteristics of the significant climate change, a direct result of some low-lying area residents were forced to migrate or small island countries and facing a stateless as a result, the climate warming causes the country residents migration, is not only a driving factor, but the first and the decisive factor. The term "environmental refugees" does not highlight the comparable causal relationship between climate change and refugee issues that the term "climate refugees" can highlight.

The UN resolution should therefore take into account legal precedents and the specific characteristics of climate refugees and establish criteria and modalities for determining who qualifies as a climate refugee. Climate refugee status should be determined in a way that reduces the cost of the aid process, ensures that rules are applied equally, eliminates repetitive arguments about cause and effect over an event, facilitates aid conditions, and effectively prevents unnecessary migration. 


\subsection{Establish An International Climate Refugee Protection Mechanism With The UN Security Council As The Center}

\subsubsection{An Independent International Specialized Agency Or Organization}

Taking a page from the UNHCR model, the UN General Assembly should set up an independent coordinating body for the special protection of climate refugees, which could be named the United Nations Special Service for Climate Refugees (or Service), reporting to and responsible to the UN General Assembly. The agency's authorization Although management should also refer to the UN's refugee agency (unhcr) mode, but should determine its own role and work, and make it suitable for climate refugees migration and resettlement of demand, in the design of its structure and policy, the agency should learn from the experience of the United Nations refugee agency (unhcr), adopt the suitable for their own organization and the way, and refine them as necessary.

In the absence of actual operations, the agency's budgetary work needs to be relatively constrained and may be funded through the general consolidated budget of the United Nations.

\subsubsection{Regional Coordination Mechanism}

A UN General Assembly resolution on the protection of climate refugees could set the basic model and framework for regional coordination mechanisms. The final outcome of the regional negotiations is the signing and adoption of a comprehensive regional agreement on the protection of the right to migration of climate refugees, the establishment of a specific legal system that is clearer and more detailed than the resolutions of the UN General Assembly, the sharing of information and the exchange of experience. The UN agency responsible for the protection of the right of climate refugees to migrate should be involved in regional negotiations and ensure that regional agreements are agreed in accordance with resolutions of the UN General Assembly.

Protection mechanism of regional climate refugees should be based on the detailed analysis of the case, according to the guidelines of the United Nations general assembly resolution, right in the climate refugees of other security agencies -- the UN specialized agencies, the global fund and the help of expert group, as much as possible to meet the climate refugees migration and resettlement of the specific needs of reality.

\subsubsection{National Legislation}

Some European and American countries have established the policy of protecting Environmental Migrants in their immigration and asylum policies.
Sweden and Finland, for example, include "environmental migrants" in their immigration and asylum policies as "persons otherwise in Need of Protection".

\subsection{Institutional Construction Of International Law For The Protection Of Climate Refugees Under The Current System}

The legal guarantee of climate refugees mainly refers to the establishment of relevant legal systems and international legal systems for the protection of climate refugees. The legal system mainly includes the international legislation system, the international coordination system, the international judicial system, the individual relief system, the scientific research system and the environmental remediation system. In terms of legal system, a fundamental law for the protection of climate refugees should be established at the level of the UN General Assembly in accordance with the Charter of the United Nations, that is, the International Convention on Climate Refugees. As the law of the highest order to protect the migration right of climate refugees, the international convention on climate refugees should stipulate the mode and responsibility mechanism of dealing with and protecting the rights and obligations of climate refugees. Secondly, according to a new climate refugees international conventions, the guidance of climate refugees in their countries of origin and other countries can be bilateral or multilateral negotiations, strive for in terms of climate refugees migration and relocation of bilateral and multilateral agreements, gradually formed to protect the basic principles and legal system are included in the provisions of the agreement, including the judicial relief of human rights climate refugees. Finally, resolutions of the United Nations General Assembly and its agencies can be considered as soft legal documents for the protection of the right to migration of climate refugees, so as to promote the implementation of conventions and agreements.

\section{CONCLUSION}

Based on the functions and powers of the Security Council and the rights of climate refugees, this paper discusses how to use the statutory powers of the Security Council to solve the problem of optimizing the relief system for the rights of climate refugees, and concludes that the concept of climate refugees and their migration rights and their legal norms should be defined, a new international climate refugee protection mechanism should be established on the basis of treaties between countries, the relief should be realized based on the framework of explicit principles of international law and international customary law. 
The main reason for the lack of relief for the rights of climate refugees lies in the absence of relevant laws in the face of increasingly severe climate change. Although natural disasters, human rights law, refugee law, environmental law, immigration law departments of international law in theory can be applied climate refugees, however the existing international law is based on the improvement of the environment changes, the creation of specific objectives for the protection of refugees and immigrants, failed to consider the problem of climate refugees at the beginning of the creation, together with the complexity of the problem, make existing specifications can not be used.

In the international climate refugee issue, the definition of climate refugees is not clear, and the use of human rights law is not premised on the subject being directly violated, so the existing laws are difficult to use.

Because there is no applicable law, the rights of refugees cannot be paid attention to, and there is no relevant system that can effectively relieve their rights. Therefore, the optimization of the system and the construction of the system are in urgent need of solving. Therefore, as the theme of this paper, the optimization of the relief system for climate refugees is of great importance to this issue.

According to the charter of the United Nations, security council is contributed to international cooperation in order to solve the international economic, social, cultural and human welfare qualitative problems of international organization, has the responsibility to participate in improving climate refugees, should be called on member states to solve the problem, and have the right to set up relevant refugee agency and other auxiliary organ and climate refugees specialized agencies. We can see the importance of the main body of this paper.

Although climate refugees have no real relief rights, they still have natural relief rights. The conclusions of this paper provide ideas for the optimization of the climate refugee relief system in practice in the future.

\section{REFERENCES}

[1] Li Wenjie. (2012). On the Predicament and Outlet of International Legislative Protection for Climate Refugees. Journal of Hainan University (Humanities and Social Sciences), 1: 67.

[2] Mayer, B. (2011). The International Legal Challenges of Climate - Induced Migration: Proposal for an International Legal Frame- work. Colorado Journal of International Environmental Law and Poli- cy, 22(3): 11-12.

[3] Farquha, H. (2015). “Migration With Dignity" : Towards a New Zealand Response to Climate
Change Displacement in the Pacific. Victoria U. Wellington L. Rev, 46: 31.

[4] Shi Xueying \& Liu Han. (2016). The Difficulties and Countermeasures in the Protection of Climate Immigrants by International Law. Nankai Journal (Philosophy and Social Sciences), 6: 68-77.

[5] Cinnamon P. Carlarne, et al. (2015). The Oxford Handbook of International Climate Change Law, Oxford: Oxford University Press.

[6] Gong Yu. (2013). Liability for Climate Change Damage in the French Context of Human Rights: Fiction or Reality. Legal Science, 1: 75-85.

[7] Hurd, I. (2013). The UN Security Council and the International Rule of Law. Journal of Zhejiang University (Humanities and Social Sciences), 43 (5): $70-81$ 